\title{
TARGETED SEQUENCING IN PATIENTS WITH CLINICALLY DIAGNOSED HEREDITARY LIPID METABOLISM DISORDER AND ACUTE CORONARY SYNDROME
}

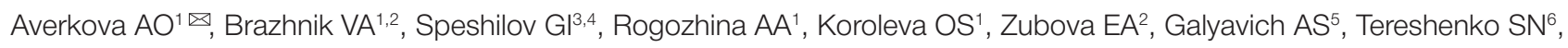
Boyeva $\mathrm{Ol}^{7}$, Zateyshchikov DA ${ }^{1,2}$

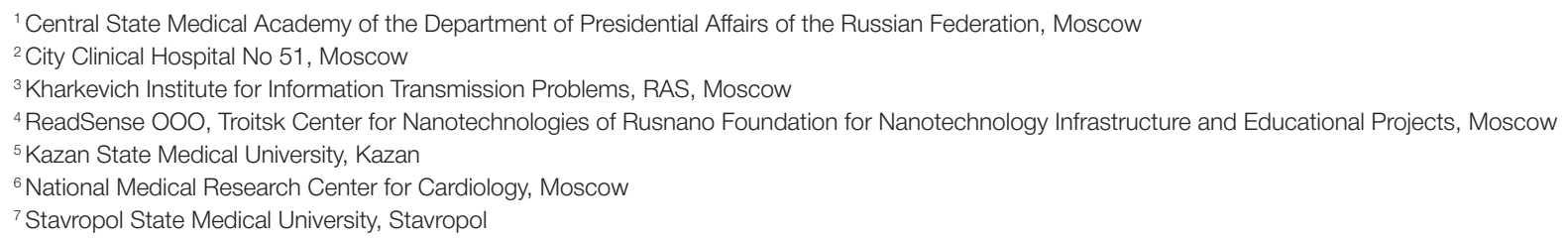

Stavropol State Medical University, Stavropol

The actual prevalence of genetic variants causing familial hypercholesterolemia (FH) in every population remains unknown. The aim of this work was to determine the spectrum of pathogenic variants in patients with acute coronary syndrome (ACS) and clinically diagnosed FH using targeted sequencing. We selected 38 patients with ACS from the sample of 2,081 participants of two multicenter observational studies (2004-2007; 2014-2016) who had a clinical diagnosis of FH based on the Dutch Lipid Clinic Network score and Simon Broome criteria. The men and women included in the study were $\leq 55$ and $\leq 60$ years of age, respectively. Molecular genetic screening was done by targeted next-generation sequencing. We started by sequencing 3 genes associated with FH, including $L D L R$, APOB, and PCSK9. If no relevant variants were detected, the panel was expanded. Of 38 patients, 24 (63.2\%) were shown to have mutations that could cause clinical manifestations of $\mathrm{FH}$ and premature coronary artery disease. All patients were heterozygous carriers. Mutations were detected in three "classic" genes $\angle D L R, A P O B$, and PCSK9 associated with FH, as well as in other genes involved in lipid metabolism, such as APOE, ABCA1, ABCG5, ABCG8, LPL, ANGPTL3, and MTTP. Five variants detected in our study sample had not been described previously: the pathogenic p.Val273_Cys313del variant of the LDLR gene, the likely pathogenic p.Arg160His variant in the APOE gene, two variants of uncertain significance p.Glu612Lys and c. ${ }^{*} 415 \mathrm{G}>\mathrm{A}$ in the PCSK9 gene, and the mutant variant p.Ala776Ser in the LDLR gene. We conclude that the use of clinical diagnostic criteria in patients with ACS and FH enables identification of carriers of both "classic" mutations associated with $\mathrm{FH}$ and rare genetic variants that can be phenotypically expressed as $\mathrm{FH}$.

Keywords: familial hypercholesterolemia, acute coronary syndrome, genetic testing, lipid metabolism disorder, targeted sequencing

$\triangle$ Correspondence should be addressed: Anastasia O. Averkova

Marshala Timoshenko 19, b. 1A, Moscow, 121359; avek@mail.ru

Received: 30.09.2018 Accepted: 05.11.2018

DOI: $10.24075 /$ brsmu.2018.061

\section{ТАРГЕТНОЕ СЕКВЕНИРОВАНИЕ У БОЛЬНЫХ С КЛИНИЧЕСКИ ДИАГНОСТИРОВАННЫМ НАСЛЕДСТВЕННЫМ НАРУШЕНИЕМ ЛИПИДНОГО ОБМЕНА И ОСТРЫМ КОРОНАРНЫМ СИНДРОМОМ}

\author{
А. О. Аверкова ${ }^{1 凶}$, В. А. Бражник ${ }^{1,2}$, Г. И. Спешилов ${ }^{3,4}$, А. А. Рогожина1, О. С. Королева , Е. А. Зубова², А. С. Галявич \\ С. Н. Терещенко ${ }^{6}$, О. И. Боева7, Д. А. Затейщиков ${ }^{1,2}$ \\ ${ }^{1}$ Центральная государственная медицинская академия Управления делами Президента РФ, Москва \\ 2 Городская клиническая больница № 51, Москва \\ ${ }^{3}$ Институт проблем передачи информации имени А. А. Харкевича РАН, Москва \\ ${ }^{4} \mathrm{OОО}$ «Ридсенс», Троицкий наноцентр ФИОП «Роснано», Москва \\ ${ }^{5}$ Казанский государственный медицинский университет, Казань \\ ${ }^{6}$ Национальный медицинский исследовательский центр кардиологии, Москва \\ ${ }^{7}$ Ставропольский государственный медицинский университет, Ставрополь
}

Истинная распространенность генетических вариантов, стоящих за развитием семейной гиперхолестеринемии (СГХС) и характерных для каждой популяции, остается неизвестной. Целью работы было определение спектра патологических генетических вариантов у больных острым коронарным синдромом (ОКС) с клинически диагностированной СГХС с помощью таргетного секвенирования. Были отобраны 38 из 2081 пациентов двух многоцентровых наблюдательных исследований больных OKC (2004-2007; 2014-2016 гт.) возрастом $\leq 55$ лет (мужчины) и 60 лет (женщины) с СГХС, клинически диагностированной по критериям Голландской сети липидных клиник и критериям регистра Simon Broome. Молекулярно-генетическое исследование проводили с помощью таргетного секвенирования следующего поколения: сначала секвенировали 3 гена, ассоциированные с СГХС: LDLR, APOB, PCSK9; при отсутствии значимых изменений панель расширяли. Из 38 пациентов у 24 (63,2\%) были выявлены генетические изменения, которые могли обусловить клинические проявления СГХС и раннюю манифестацию ишемической болезни сердца. Все пациенты являлись гетерозиготными носителями генетических вариантов. Выявлены варианты в трех основных генах (LDLR, APOB, PCSK9), связанных с СГХС, и редкие варианты в других генах системы липидного обмена (APOE, ABCA1, ABCG5, ABCG8, LPL, ANGPTL3, MTTP). Пять генетических вариантов описаны впервые: патогенный вариант p.Val273_Cys313del гена LDLR; вероятно патогенный вариант p.Arg160His гена APOE; варианты неуточненной клинической значимости p.Glu612Lys и c. *415G>A гена PCSK9; вариант p.Ala776Ser гена LDLR. Taким образом, использование клинических критериев позволяет выявить среди пациентов с ОКС и СГХС носителей мутаций не только «классических» генов, связанных с СГХС, но и редких, способных приводить к фенотипическим проявлениям СГХС.

Ключевые слова: семейная гиперхолестеринемия, острый коронарный синдром, генетическое обследование, нарушение липидного обмена, таргетное секвенирование

$\triangle$ Для корреспонденции: Анастасия Олеговна Аверкова ул. Маршала Тимошенко, д. 19, стр. 1А, г. Москва, 121359; avek@mail.ru Статья получена: 30.09.2018 Статья принята к печати: 05.11.2018 DOI: $10.24075 /$ vrgmu.2018.061 
One of the known causes of premature coronary artery disease (CAD) is familial hypercholesterolemia (FH), a hereditary lipid metabolism disorder that increases the risk of developing cardiovascular disease twentyfold [1]. It is the most common monogenic autosomal-dominant lipid metabolism disorder characterized by elevated low-density lipoprotein (LDL) cholesterol. The majority (60-80\%) of patients with clinically established heterozygous $\mathrm{FH}$ carry mutations in the gene coding for the $L D L$ receptor $(L D L R)$; the prevalence of each implicated mutation varies geographically. These mutant variants result in fewer $L D L$ receptor molecules on the cell surface or their decreased activity. The $L D L R$ gene is located on the short arm of chromosome 19 and consists of 18 exons transcribed and translated into 5 LDLR-forming domains [2] About $5-10 \%$ patients with heterozygous $\mathrm{FH}$ have mutations in the $A P O B$ gene that are phenotypically expressed as a less pronounced elevation of cholesterol levels; these mutant variants are more common in Central Europe than in other regions [3]. The defect in the ApoB100 protein, a component of LDL particles, prevents it from binding to LDLRs. $A P O B$ has been mapped to chromosome $2 \mathrm{p}$ and comprises 29 exons [2]. Gain-of-function (GOF) mutations of the proprotein convertase subtilisin/kexin type 9 gene (PCSK9) are another cause of autosomal-dominant $\mathrm{FH}$ accounting for $<1 \%$ of all $\mathrm{FH}$ cases in the majority of the studied populations. GOF variants lead to rapid LDLR internalization and downregulate the number of LDLR molecules. The PCSK9 gene sits on the short arm of chromosome 1p32 and is constituted by 12 exons and 11 introns $[4,5]$. Mutations in other genes involved in lipid metabolism rarely cause $\mathrm{FH}$ [3]. Some patients carry two mutations in the genes associated with $\mathrm{FH}$. Unfortunately, in 20 to $40 \%$ of patients with clinically confirmed $\mathrm{FH}$ the causative mutation cannot be identified.

The aim of this work was to determine the spectrum of pathogenic variants involved in lipid metabolism in patients with acute coronary syndrome (ACS) and a clinical diagnosis of FH by targeted sequencing.

\section{METHODS}

For this study we used the samples obtained from 2,081 patients with ACS who had participated in two multicenter observational studies carried out in 4 centers in Moscow, Kazan and Stavropol. The patients had been recruited in 2004 through 2007 and in 2014 through 2016. The study protocol was described in [6]. The study was approved by the Ethics Committee of the Medical Educational Research Center of the Department of Presidential Affairs of the Russian Federation (Protocol 14/14 dated October 20, 2014).

We selected 326 patients from the $1^{\text {st }}$ and 374 patients from the $2^{\text {nd }}$ recruitment periods. Over the first recruitment period the inclusion criteria were as follows: premature ACS (at $\leq 55$ years of age in men and at $\leq 60$ years in women); ACS with an onset at least 10 days before index admission to hospital; FH diagnosis based on the Dutch Lipid Clinic Network score and Simon Broome criteria [7, 8]; written informed consent to participate. During the second recruitment period the inclusion criteria were the same but additionally those patients were included who had indications for percutaneous coronary intervention $(\mathrm{PCl})$, regardless of whether the latter was eventually performed or not.

The diagnosis of $\mathrm{FH}$ was based on the Dutch Lipid Clinic Network (DLCN) score and Simon Broome criteria. Generally, the DLCN set of criteria accounts for the patient's family history, early CAD onset in the patient, physical examination (tendinous xanthomas, corneal arcus), and LDL levels. Patients who score more than 8 points are concluded to have definite $\mathrm{FH}$; 6-8 points, probable $\mathrm{FH}$; $3-5$ points, possible $\mathrm{FH}$; less than 3 points, unlikely FH [7]. The Simon Broome criteria account for the total cholesterol and LDL levels, the age of the patient and their kinship to a relative who also has elevated LDL and cholesterol. In the clinical setting, only possible $\mathrm{FH}$ can be detected; the diagnosis of definite $\mathrm{FH}$ cannot be established without identifying its causative mutation [8].

Molecular genetic screening was performed on the samples of 38 patients selected using the following algorithm. Patients enrolled during the first recruitment period were eligible for the genetic screening if they scored $\geq 5$ points on the DLCN scale or scored 4 points on the DLCN scale and also had FH according to the Simon Broome criteria (a total of 10 people). Patients recruited during the second period were eligible if they scored $\geq 5$ points on the DLCN scale or met the Simon Broome criteria and had a family history of cardiovascular disorders (a total of 24 individuals). This second sample also included 4 patients who did not have premature ACS at the time of hospital admission but still had an episode of early CAD manifestation according to their medical history $(\geq 6$ points on the DLCN scale or 5 points on the DLCN scale + a family history of cardiovascular disorders).

Sequencing was carried out in the ReadSense laboratory (Moscow). DNA was isolated from blood samples using the K-Sorb DNA isolation kit (Syntol; Russia) and spin columns. Preparation of DNA libraries was aided by the NEB Next Ultra kit (NEB; USA). Capture-based enrichment of target protein-coding regions was done using the NimbleGen panel of biotinylated probes (Roche; USA). Quality of the enriched DNA libraries was assessed by capillary gel electrophoresis on BioAnalyzer 2100 (Agilent; USA) and Qubit fluorometer (Invitrogen; USA). The libraries were sequenced using the 300-cycle v2 MiSeq reagent kit on the Illumina MiSeq nextgeneration sequencer (Illumina; USA) set up according to the manufacturer's recommendations.

First, 3 genes associated with $\mathrm{FH}$ were sequenced, including $\angle D L R, A P O B$, and PCSK9. Then, if no relevant variants were detected, the panel was expanded to cover the entire range of genes involved in lipid metabolism: APOA1, APOA5, APOC2, APOE, APOC3, ABCA1, ABCG1, ABCG5, ABCG8, ANGPTL3, CEL, CH25H, CPT2, CYP2D6, CYP3A4, CYP3A5, GPD1, GPIHBP1, INSIG2, LCAT, LDLRAP1, LIPA, LMF1, LPA, LPL, MTTP, NPC1L1, PNPLA2, PPARA, and SAR1B.

A number of steps were taken to evaluate the quality of the enrichment panel. The reads obtained for each sample were mapped to the reference human genome (GRCh37.p13 hg19). To understand whether sequencing coverage was sufficient, we analyzed the nucleotides used for probe synthesis that were covered at a minimum of 20x. Once detected, the target mutations were annotated using HGMD, COSMIC, ClinVar, 1000 GenomesProject, dbSNP, and ExAC databases. Conservation of substitutions was estimated by a number of prediction tools (POLYPHEN, SIFT, MUTATION TASTER, FATHMM, CADD, DANN, and EIGEN). Mutant variants were annotated as recommended by ACMG [9].

\section{RESULTS}

All patients who carried variants of the studied genes were heterozygous. Variants of the three "classic" genes implicated in $\mathrm{FH}$ were detected in 11 patients.

Among them were 3 pathogenic and likely pathogenic variants of the $L D L R$ gene and one variant with uncertain 
Table. Sequencing results in patients with premature ACS and clinically established FH

\begin{tabular}{|c|c|c|c|c|c|c|c|c|c|}
\hline No & Sex & Age & $\begin{array}{l}\text { Family } \\
\text { history }\end{array}$ & $\begin{array}{l}\mathrm{LDL} . \\
\mathrm{mmol} / \mathrm{l}\end{array}$ & $\begin{array}{l}\text { DLCN } \\
\text { score }\end{array}$ & $\begin{array}{l}\text { FH. Simon } \\
\text { Broome registry }\end{array}$ & Result & Pathogenicity & $\begin{array}{l}\text { Population } \\
\text { frequency }\end{array}$ \\
\hline 1 & $\mathrm{~F}$ & 48 & + & 9.6 & 11 & + & $\begin{array}{l}\text { Gene LDLR p.Val273_Cys313del; } \\
\text { c.817+303_940+943del }\end{array}$ & Pathogenic & Not described \\
\hline 2 & $M$ & 53 & - & 9.1 & 11 & + & Not detected & - & - \\
\hline 3 & M & 46 & + & 6.9 & 8 & + & $\begin{array}{l}\text { 1. Gene } L D L R \text { p.Gly20Arg; c.58G }>\mathrm{A} \\
\text { 2. Gene PCSK9 p.Glu612Lys; c. } 1834 \mathrm{G}>\mathrm{A}\end{array}$ & $\begin{array}{l}\text { 1. Likely pathogenic } \\
\text { 2. Of uncertain } \\
\text { significance }\end{array}$ & $\begin{array}{l}\text { 1. }<1 \% \\
\text { 2. Not } \\
\text { described }\end{array}$ \\
\hline 4 & $\mathrm{~F}$ & 51 & + & 5.9 & 6 & + & $\begin{array}{l}\text { Polymorphism of gene APOE p.Cys } 130 \text { Arg; } \\
\text { c.388T>C; isoform apoE4 }\end{array}$ & Modifying factor & $>1 \%$ \\
\hline 5 & $M$ & 46 & + & 5.6 & 6 & + & Not detected & - & - \\
\hline 6 & $M$ & 49 & + & 5.1 & 6 & + & Not detected & - & - \\
\hline 7 & $\mathrm{~F}$ & 57 & + & 5.7 & 6 & + & Gene LDLR p.Ala776Ser; c.2326G>T & Of uncertain significance & $\begin{array}{c}\text { Not } \\
\text { described }\end{array}$ \\
\hline 8 & $\mathrm{~F}$ & 59 & + & 5.2 & 6 & + & Not detected & - & - \\
\hline 9 & M & 52 & + & 6.2 & 6 & + & $\begin{array}{l}\text { 1. Polymorphism of gene } A P O E \\
\text { p.Cys } 130 \text { Arg; c. } 388 T>C \text {; isoform apoE } 4 \\
\text { 2. Gene } A P O B \text { p.Ala4002Val; c. } 12005 C>T\end{array}$ & $\begin{array}{l}\text { 1. Modifying factor } \\
\text { 2. Of uncertain } \\
\text { significance }\end{array}$ & $\begin{array}{l}\text { 1. }>1 \% \\
\text { 2. }<1 \%\end{array}$ \\
\hline 10 & M & 55 & + & 6.2 & 6 & + & Gene $P C S K 9$ c. ${ }^{*} 415 \mathrm{G}>\mathrm{A}$ & Of uncertain significance & $\begin{array}{c}\text { Not } \\
\text { described }\end{array}$ \\
\hline 11 & M & 54 & + & 6.5 & 6 & + & Gene ABCG8 p.Ala642Thr; c.G1924A & Of uncertain significance & $<1 \%$ \\
\hline 12 & M & 54 & + & 5.1 & 6 & + & Not detected & - & - \\
\hline 13 & M & 36 & + & 5.6 & 6 & - & Gene APOE p.Arg180Cys; c.C538T & Likely pathogenic & $<1 \%$ \\
\hline 14 & M & 34 & $\mathrm{~N} / \mathrm{A}$ & 5.4 & 5 & + & $\begin{array}{l}\text { Polymorphism of gene APOE p.Cys130Arg; } \\
\text { c.388T>C; isoform apoE4 }\end{array}$ & Modifying factor & $>1 \%$ \\
\hline 15 & M & 53 & $\mathrm{~N} / \mathrm{A}$ & 5.2 & 5 & + & Not detected & - & - \\
\hline 16 & $\mathrm{~F}$ & 56 & $\mathrm{~N} / \mathrm{A}$ & 5.5 & 5 & - & Not detected & - & - \\
\hline 17 & M & 44 & - & 5.8 & 5 & + & Gene $L D L R$ p.Gly20Arg; c.58G $>\mathrm{A}$ & Likely pathogenic & $<1 \%$ \\
\hline 18 & M & 50 & - & 5.1 & 5 & + & Not detected & - & - \\
\hline 19 & $\mathrm{~F}$ & 58 & - & 5.0 & 5 & - & Gene $A P O E$ p.Arg160His; c. $479 \mathrm{G}>\mathrm{A}$ & Likely pathogenic & Not described \\
\hline 20 & M & 55 & - & 6.3 & 5 & - & Not detected & - & - \\
\hline 21 & M & 51 & + & 4.0 & 4 & + & $\begin{array}{l}\text { Polymorphism of gene APOE p.Cys130Arg; } \\
\text { c.388T>C; isoform apoE4 }\end{array}$ & Modifying factor & $>1 \%$ \\
\hline 22 & $\mathrm{~F}$ & 57 & + & 4.0 & 4 & + & Gene $A B C A 1$ p.Pro85Leu; c.C254T & Likely pathogenic & $<1 \%$ \\
\hline 23 & M & 43 & + & 4.9 & 4 & + & Gene LPL p.Thr379lle; c.C1136T & Likely pathogenic & $<1 \%$ \\
\hline 24 & M & 53 & + & 4.6 & 4 & + & Gene LDLR p.Glu208Lys; c.G622A & Pathogenic & $<1 \%$ \\
\hline 25 & M & 47 & + & 5.4 & 6 & + & $\begin{array}{l}\text { Gene ANGPTL3 p.Asn } 147^{\star} ; \\
\text { c.431_434del }\end{array}$ & $\begin{array}{c}\text { Pathogenic. familial } \\
\text { hypobetalipoproteinemia }\end{array}$ & $<1 \%$ \\
\hline 26 & $\mathrm{~F}$ & 54 & + & 5.0 & 6 & + & Not detected & - & - \\
\hline 27 & M & 39 & + & 5.3 & 6 & + & Gene $A B C G 5$ p.Gly27Ala; c.G80C & $\begin{array}{l}\text { Likely pathogenic. } \\
\text { sitosterolemia/ } \\
\text { hypercholesterolemia }\end{array}$ & $<1 \%$ \\
\hline 28 & M & 46 & + & 6.5 & 6 & + & Gene MTTP p.Leu838Phe; c.G2514C & Of uncertain significance & $<1 \%$ \\
\hline 29 & $M$ & 45 & + & 5.0 & 6 & + & Not detected & - & - \\
\hline 30 & M & 42 & + & 4.8 & 6 & - & Not detected & - & - \\
\hline 31 & M & 51 & $\mathrm{~N} / \mathrm{A}$ & 5.2 & 5 & + & Gene $A B C G 8$ p.Leu572Pro; c.T1715C & Pathogenic. sitosterolemia & $<1 \%$ \\
\hline 32 & $\mathrm{~F}$ & 47 & $\mathrm{~N} / \mathrm{A}$ & 5.7 & 5 & - & Gene $A P O B$ p.Val4265Ala; c.T12794C & Likely pathogenic & $<1 \%$ \\
\hline 33 & M & 48 & - & 4.9 & 5 & - & Not detected & - & - \\
\hline 34 & $\mathrm{~F}$ & 59 & + & 4.9 & 4 & + & Gene $A B C A 1$ p.Val399Ala; c.T1196C & $\begin{array}{l}\text { Pathogenic. congenital } \\
\text { HDL deficiency }\end{array}$ & $<1 \%$ \\
\hline 35 & $M$ & 56 & + & 6.5 & 7 & - & Not detected & - & - \\
\hline 36 & M & 64 & + & 5.0 & 6 & + & Gene $A P O B$ p.Ser3279Gly; c.A9835G & Likely pathogenic & $<1 \%$ \\
\hline 37 & M & 57 & + & 5.8 & 6 & + & Gene $A P O B$ p.Asn2971Thr; c.A8912C & Of uncertain significance & $<1 \%$ \\
\hline 38 & $\mathrm{~F}$ & 64 & + & 5.6 & 5 & - & Gene $A B C A 1$ p.Arg496Trp; c.C1486T & $\begin{array}{l}\text { Possibly pathogenic. } \\
\text { congenital HDL deficiency }\end{array}$ & $<1 \%$ \\
\hline
\end{tabular}


clinical significance. Of them, one deleterious mutation (p.Val273_Cys313del) was previously undescribed. It is an in-frame deletion in exon 6 resulting in a missing class A7 domain at the N-terminus of the LDLR [10]. This mutation belongs to class 3 of $L D L R$ mutations leading to the production of a defective receptor that cannot bind to LDL. A similar mutation g.11218068_11218190del was described by Usifo et al. [11]. Another mutation detected in our sample yet previously undescribed (p.Ala776Ser) is located in exon 16 and has uncertain significance. Such rare missense mutations observed in the general population are normally classified as non-pathogenic. However, we cannot completely rule out their contribution to hypercholesterolemia [12]. The likely pathogenic mutation p.Gly20Arg in the LDLR gene occurred in two patients. The pathogenic mutation p.Glu208Lys was detected in one patient.

Pathogenic and likely pathogenic $A P O B$ variants were observed in two patients. Two more patients carried mutant $A P O B$ variants of uncertain significance. The population frequency of all APOB mutations identified in our study is less than $1 \%$.

Two patients carried previously undescribed PCSK9 mutations of uncertain significance. One of them (p.Glu612Lys) is located in exon 11. PCSK9 mutations resulting in the modification of the functional cysteine- and histidine-rich C-terminal domain are known to be associated with $\mathrm{FH}$. Specifically, these genetic variants add to the severity of hypercholesterolemic phenotype in patients who also have mutations in the LDLR gene (our patient also had a likely pathogenic mutation p.Gly20Arg in this gene) [13]. The second PCSK9 mutation c. ${ }^{\star} 415 \mathrm{G}>\mathrm{A}$ is located in exon 12 . This region is untranslatable and contains elements responsible for PCSK9 expression. However, it is impossible to predict the functional consequences of this genetic variation.
Patients with clinically established $\mathrm{FH}$ had mutations in other genes involved in lipid metabolism, such as APOE, which turned to be mutant in two participants. One of those patients had a previously undescribed and likely pathogenic mutation (p.Arg160His) located in exon 4. This genomic region is involved in the binding of the APOE lipoprotein to LDLR. Its mutant variants have been shown to be associated with autosomal-dominant familial dysbetalipoproteinemia [14]. Four participants carried the $\varepsilon 4$ allele of the APOE gene resulting in the atherogenic isoform of apolipoprotein $E$ (one of those patients also had the p.Ala4002Val variant of uncertain significance in the $A P O B$ gene).

Three patients had $A B C A 1$ mutations; of them one was pathogenic and two likely pathogenic implicated in low HDL. Two patients were found to have ABCG8 mutations thought to be associated with sitosterolemia: one was pathogenic and another one of uncertain significance [15]. One patient had a likely pathogenic mutation in the ABCG5 gene; one patient carried a possibly pathogenic mutation in the LPL gene; one bore a pathogenic mutation in ANGPTL3; another, a mutation of uncertain significance in the MTTP gene.

Thus, of 38 patients with clinically established $\mathrm{FH} 24$ (63.2\%) carried variants that could be phenotypically expressed as $\mathrm{FH}$ or early CAD. Five of the identified variants were previously undescribed.

The results of our study are presented in the Table below and in Fig. 1.

\section{DISCUSSION}

The prevalence of $\mathrm{FH}$ in the general population is $0.2-0.5 \%$, but in patients with ACS it can be as high as $8 \%$. Therefore, its accurate diagnosis in this particular subpopulation is very important as it enables adequate lipid-lowering therapy and

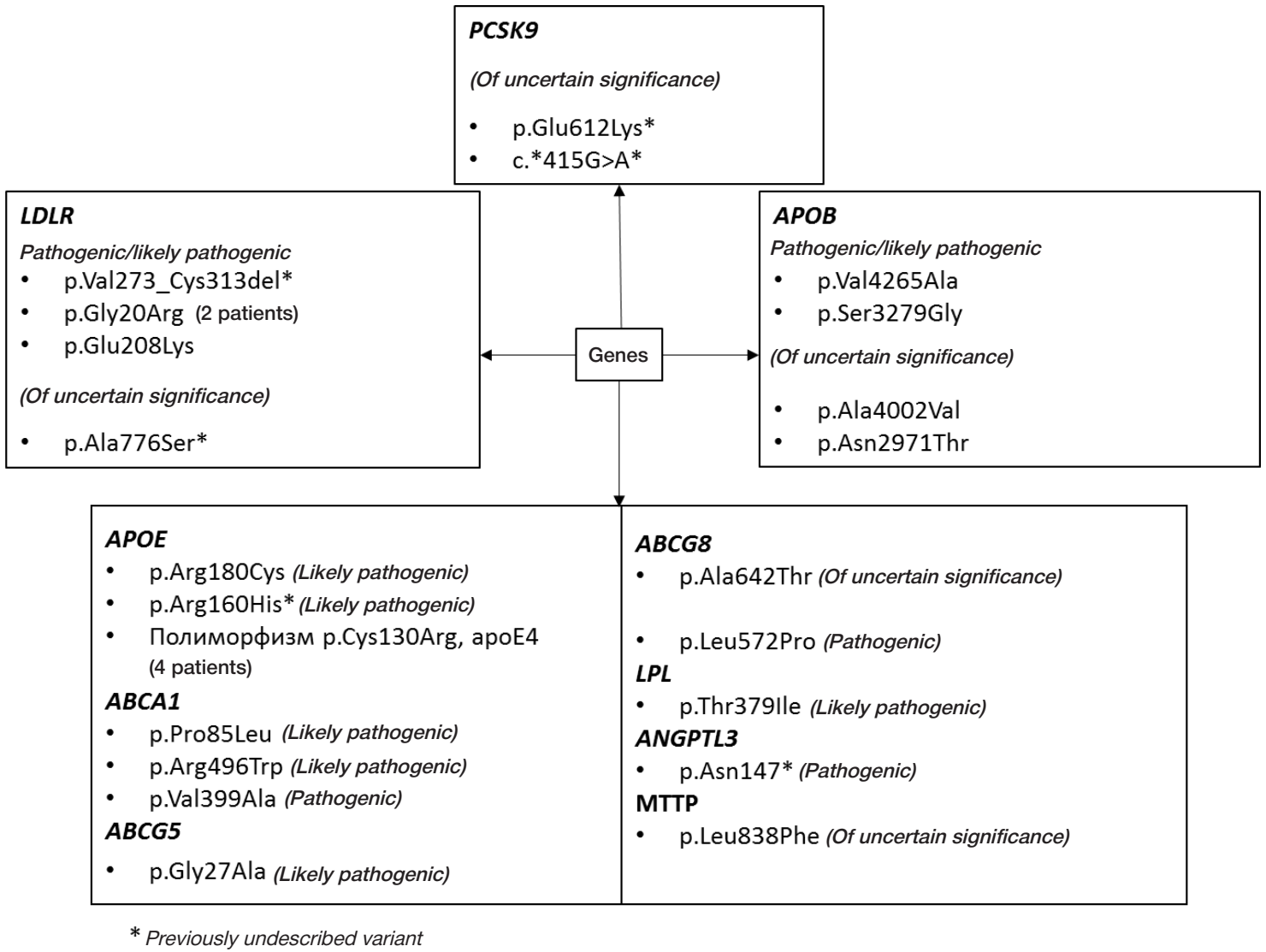

Fig. 1. Genetic variants associated with clinically diagnosed FH in patients with early ACS 
initiate cascade screening [16, 17]. In Russia the first steps are being taken in investigating the prevalence of mutations implicated in $\mathrm{FH}$ [18]. However, we already know about the extreme genetic heterogeneity and the absence of the founder effect demonstrated by a research team from Saint Petersburg [19]. They screened a group of patients with $\mathrm{FH}$ who did not have ACS and found no carriers of mutant $A P O B$. Another research work conducted in Northwest part of Russia also showed the absence of $A P O B$ mutations in the studied subpopulation [20]. In our sample of patients with premature ACS, $L D L R$ and $A P O B$ mutant variants were equally represented (4 mutant variants of $L D L R$ of which 3 were pathogenic or likely pathogenic and one was present in two patients; 4 mutant variants of $A P O B$ of which two were pathogenic or likely pathogenic). Interestingly, there were 2 patients in our sample with the $\mathrm{FH}$ phenotype who carried mutations of uncertain significance in the PCSK 9 gene. So far, only a few cases of PCSK9 variants have been described in the Russian population [21]. All known deleterious mutations of PCSK 9 are very rare and have an allelic frequency of $<0.1 \%$ in the general population [22]. Distribution of SNPs in the general population only mildly affecting cholesterol metabolism demonstrates a balance between the alleles that up- and downregulate the levels of LDL. In the individuals at the extreme ends of this spectrum, alleles that increase LDL levels are hereditarily prevalent; together these alleles can cause elevated LDL characteristic of heterozygous $\mathrm{FH}$. One of the most typical and well-studied examples of such single nucleotide polymorphisms is the $\varepsilon 2 / \varepsilon 3 / \varepsilon 4$ polymorphism of the APOE gene. The risk of developing CAD increases in the carriers of the $\varepsilon 4$ allele manifold $[23,24]$. The $\varepsilon 4$ allele of p.Cys130Arg has been shown to be associated with $\mathrm{FH}$ in the Russian population [25], which is also confirmed by the present study that has identified this polymorphism in 4 patients. Importantly, the actual frequency of rare variants in other genes involved in lipid metabolism, including $A P O E, A B C A 1, A B C G 5, A B C G 8$, $\angle P L, A N G P T L 3$, and MTTP, may be different from what we believe in the subpopulation of Russian patients with ACS and $\mathrm{FH}$. Patient 1 (see the Table) carried a previously undescribed but definitely pathogenic mutation p.Val273_Cys313del in the $L D L R$ gene [11]. The proband's daughter also had elevated total cholesterol and underwent a cascade screening procedure, which found no presence of the pathogenic variant in her genome. To sum up, of 38 patients 14 (36.8\%) had pathogenic or likely pathogenic variants and $10(26.3 \%)$ carried variants of uncertain significance. The literature does not provide us with the data on the frequency of $\mathrm{FH}$-associated variants in patients with premature ACS. However, the authors who conducted target sequencing in 104 patients with a clinical diagnosis of $\mathrm{FH}$ revealed the presence of pathogenic variants both in the "classic" genes, including $\angle D L R, A P O B$, and PCSK9, and rare genes involved in lipid metabolism in $67 \%$ of the participants with definite $\mathrm{FH}[26]$.

\section{CONCLUSIONS}

The use of clinical diagnostic tests followed by targeted sequencing helps to identify pathogenic variants not only in the "classic" genes implicated in FH but also in the "rare" genes that might be associated with the $\mathrm{FH}$ phenotype in patients with ACS and FH.

\section{References}

1. Braenne I, Kleinecke M, Reiz B, Graf E, Strom T, Wieland T et al. Systematic analysis of variants related to familial hypercholesterolemia in families with premature myocardial infarction. Eur J Hum Genet. 2016; 24 (2): 191-7.

2. Sharifi M, Futema M, Nair D, Humphries SE. Genetic Architecture of Familial Hypercholesterolaemia. Current Cardiology Reports. 2017; 19(5): 1-8.

3. Defesche JC, Gidding SS, Harada-Shiba M, Hegele RA, Santos RD, Wierzbicki AS. Familial hypercholesterolaemia. Nature Reviews Disease Primers. 2017; (3): 1-20.

4. Ouguerram K, Chetiveaux M, Zair $\mathrm{Y}$, Costet $\mathrm{P}$, Abifadel $\mathrm{M}$, Varret $\mathrm{M}$ et al. Apolipoprotein B100 metabolism in autosomaldominant hypercholesterolemia related to mutations in PCSK9. Arteriosclerosis, Thrombosis, and Vascular Biology. 2004; 24 (8): 1448-53.

5. Sun H, Samarghandi A, Zhang N, Yao Z, Xiong M, Teng BB. Proprotein convertase subtilisin/kexin type 9 interacts with apolipoprotein B and prevents its intracellular degradation, irrespective of the low-density lipoprotein receptor. Arteriosclerosis, Thrombosis, and Vascular Biology. 2012; 32 (7): 1585-95.

6. Zatejshhikov DA, Volkova JeG, Guz IO, Evdokimova MA, Asejcheva OJu, Galjavich AS i dr. Lechenie bol'nyh, perenesshih ostryj koronarnyj sindrom, po dannym Rossijskogo mnogocentrovogo prospektivnogo nabljudatel'nogo issledovanija. Farmateka. 2009; (12): 109-13.

7. Catapano AL, Graham I, De Backer G, Wiklund O, Chapman MJ, Drexel $\mathrm{H}$ et al. 2016 ESC/EAS Guidelines for the Management of Dyslipidaemias. Eur Heart Journal. 2016; 37 (39): 2999-3058.

8. Wierzbicki AS, Humphries SE, Minhas R. Familial hypercholesterolaemia: summary of NICE guidance. British Medical Journal. 2008; (337): 1095.

9. Richards S, Aziz N, Bale S, Bick D, Das S, Gastier-Foster J et al. Standards and guidelines for the interpretation of sequence variants: a joint consensus recommendation of the American College of Medical Genetics and Genomics and the Association for Molecular Pathology. Genet Med. 2015; 17 (5): 405-24.

10. Averkova AO, Brazhnik VA, Koroleva OS, Zubova EA, Rogozhina AA, Hasanov NR et al. Osobennosti porazheniya koronarnogo rusla i techeniya ostrogo koronarnogo sindroma u molodyh bol'nyh s semejnoj giperlipidemiej po dannym nablyudatel'nogo proekta ORAKUL II. Kompleksnye problemy serdechno-sosudistyh zabolevanij. Prilozhenie. 2017; 6 (4): 9.

11. Usifo E, Leigh SEA, Whittall RA, Lench N, Taylor A, Yeats C et al. Low-Density Lipoprotein Receptor Gene Familial Hypercholesterolemia Variant Database: Update and Pathological Assessment. Annals of Human Genetics. 2012; 76 (5): 387-401.

12. Bertolini S, Pisciotta L, Rabacchi C, Cefalu AB, Noto D, Fasano T et al. Spectrum of mutations and phenotypic expression in patients with autosomal dominant hypercholesterolemia identified in Italy. Atherosclerosis. 2013; 227 (2): 342-8.

13. Pisciotta L, Priore Oliva C, Cefalu AB, Noto D, Bellocchio A, Fresa R et al. Additive effect of mutations in LDLR and PCSK9 genes on the phenotype of familial hypercholesterolemia. Atherosclerosis. 2006; 186 (2): 433-40.

14. Wintjens R, Bozon D, Belabbas K, MBou F, Girardet JP, Tounian PA et al. Global molecular analysis and APOE mutations in a cohort of autosomal dominant hypercholesterolemia patients in France. Journal of lipid research. 2016; 57 (3): 482-91.

15. Lu K, Lee MH, Hazard S, Brooks-Wilson A, Hidaka H, Kojima H et al. Two genes that map to the STSL locus cause sitosterolemia: genomic structure and spectrum of mutations involving sterolin-1 and sterolin-2, encoded by ABCG5 and ABCG8, respectively. Am J Hum Genet. 2001; 69 (2): 278-90.

16. De Backer G, Besseling J, Chapman J, Hovingh GK, Kastelein JJP, Kotseva $K$ et al. Prevalence and management of familial hypercholesterolaemia in coronary patients: An analysis of 
EUROASPIRE IV, a study of the European Society of Cardiology. Atherosclerosis. 2015; 241 (1): 169-75.

17. Nordestgaard BG, Chapman MJ, Humphries SE, Ginsberg HN Masana L, Descamps OS et al. Familial hypercholesterolaemia is underdiagnosed and undertreated in the general population: guidance for clinicians to prevent coronary heart disease: consensus statement of the European Atherosclerosis Society. European Heart Journal. 2013; 34 (45): 3478-90a.

18. Ezhov MV, Sergienko IV, Duplyakov DV, Abashina OE, Kachkovskiy MA Shaposhnik II et al. Rezul'taty Rossijskoj nauchnoissledovatel'skoj programmy po diagnostike i lecheniyu bol'nyh semejnoj giperholesterinemiej. Vysokaya rasprostranennost', nizkaya informirovannost', plohaya priverzhennost'. Ateroskleroz i dislipidemii. 2017; (2): 5-15.

19. Zaharova FM, Tatishcheva YA, Golubkov VI, Lipoveckij BM, Konstantinov VO, Denisenko AD et al. Semejnaya giperholesterinemiya $\vee$ Sankt-Peterburge: raznoobrazie mutaci svidetel'stvuet ob otsutstvii vyrazhennogo ehffekta osnovatelya. Genetika. 2007; 43 (9): 1255-62.

20. Korneva VA, Bogoslovskaya TY, Kuznecova TY, Mandelshtam MY, Vasilev BV. Semejnaya giperholesterinemiya, obsulovlennaya novoj mutaciej gena receptorov lipoproteinov nizkoj plotnosti. Klinicheskaya medicina. 2014; (7): 49-53.

21. Shakhtshneider EV, Makarenkova KV, Astrakova KS, Ivanoshchuk DE,
Orlov PS, Ragino YI et al. Targetnoe sekvenirovanie gena PCSK9 u pacientov semejnoj giperholesterinemiej v Rossii. Kardiologiya. 2017; (6): 46-51.

22. Kosenko T, Golder M, Leblond G, Weng W, Lagace TA. Low density lipoprotein binds to proprotein convertase subtilisin/kexin type-9 (PCSK9) in human plasma and inhibits PCSK9-mediated low density lipoprotein receptor degradation. The Journal of biological chemistry. 2013; 288 (12): 8279-88.

23. Bennet AM, Di Angelantonio E, Ye Z, Wensley F, Dahlin A, Ahlbom A et al. Association of apolipoprotein $E$ genotypes with lipid levels and coronary risk. Jama. 2007; 298 (11): 1300-11.

24. Luo JQ, Ren H, Banh HL, Liu MZ, Xu P, Fang PF et al. The Associations between Apolipoprotein E Gene Epsilon2/Epsilon3/ Epsilon4 Polymorphisms and the Risk of Coronary Artery Disease in Patients with Type 2 Diabetes Mellitus. Frontiers in physiology. 2017; (8): 1031

25. Shakhtshneider EV, Ragino YI, Chernjavski AM, Kulikov IV, Ivanova MV, Voevoda MI. Apolipoprotein E gene polymorphism in men with coronary atherosclerosis in Siberia. Bulletin of experimental biology and medicine. 2011; 150 (3): 355-8.

26. Vandrovcova J, Thomas ER, Atanur SS, Norsworthy PJ, Neuwirth C, Tan $Y$ et al. The use of next-generation sequencing in clinical diagnosis of familial hypercholesterolemia. Genet Med. 2013; 15 (12): 948-57.

\section{Литература}

1. Braenne I, Kleinecke M, Reiz B, Graf E, Strom T, Wieland T et al. Systematic analysis of variants related to familial hypercholesterolemia in families with premature myocardial infarction. Europ J Hum Genet. 2016; 24 (2): 191-7.

2. Sharifi M, Futema M, Nair D, Humphries SE. Genetic Architecture of Familial Hypercholesterolaemia. Current Cardiology Reports. 2017; 19 (5): 1-8.

3. Defesche JC, Gidding SS, Harada-Shiba M, Hegele RA, Santos RD, Wierzbicki AS. Familial hypercholesterolaemia. Nature Reviews Disease Primers. 2017; (3): 1-20.

4. Ouguerram K, Chetiveaux M, Zair $Y$, Costet $P$, Abifadel $M$, Varret $\mathrm{M}$ et al. Apolipoprotein B100 metabolism in autosomaldominant hypercholesterolemia related to mutations in PCSK9. Arteriosclerosis, Thrombosis, and Vascular Biology. 2004; 24 (8): 1448-53.

5. Sun H, Samarghandi A, Zhang N, Yao Z, Xiong M, Teng BB. Proprotein convertase subtilisin/kexin type 9 interacts with apolipoprotein B and prevents its intracellular degradation, irrespective of the low-density lipoprotein receptor. Arteriosclerosis, Thrombosis, and Vascular Biology. 2012; 32 (7): 1585-95.

6. Затейщиков Д. А., Волкова Э. Г., Гузь И. О., Евдокимова М. А., Асейчева О. Ю., Галявич А. С. и др. Лечение больных, перенесших острый коронарный синдром, по данным Российского многоцентрового проспективного наблюдательного исследования. Фарматека. 2009; (12): 109-13.

7. Catapano AL, Graham I, De Backer G, Wiklund O, Chapman MJ, Drexel $\mathrm{H}$ et al. 2016 ESC/EAS Guidelines for the Management of Dyslipidaemias. European Heart Journal. 2016; 37 (39): 29993058

8. Wierzbicki AS, Humphries SE, Minhas R. Familial hypercholesterolaemia: summary of NICE guidance. British Medical Journal. 2008; (337): 1095.

9. Richards S, Aziz N, Bale S, Bick D, Das S, Gastier-Foster J et al. Standards and guidelines for the interpretation of sequence variants: a joint consensus recommendation of the American College of Medical Genetics and Genomics and the Association for Molecular Pathology. Genet Med. 2015; 17 (5): 405-424.

10. Аверкова А. О., Бражник В. А., Королева О. С., Зубова Е. А., Рогожина А. А., Хасанов Н. Р. и др. Особенности поражения коронарного русла и течения острого коронарного синдрома у молодых больных с семейной гиперлипидемией по данным наблюдательного проекта ОРАКУЛ ІІ. Комплексные проблемы сердечно-сосудистых заболеваний. Приложение. 2017; 6 (4): 9.
11. Usifo E, Leigh SEA, Whittall RA, Lench N, Taylor A, Yeats C et al. Low-Density Lipoprotein Receptor Gene Familial Hypercholesterolemia Variant Database: Update and Pathological Assessment. Annals of Human Genetics. 2012; 76 (5): 387-401.

12. Bertolini S, Pisciotta L, Rabacchi C, Cefalu AB, Noto D, Fasano T et al. Spectrum of mutations and phenotypic expression in patients with autosomal dominant hypercholesterolemia identified in Italy. Atherosclerosis. 2013; 227 (2): 342-8.

13. Pisciotta L, Priore Oliva C, Cefalu AB, Noto D, Bellocchio A, Fresa R et al. Additive effect of mutations in LDLR and PCSK9 genes on the phenotype of familial hypercholesterolemia. Atherosclerosis. 2006; 186 (2): 433-40.

14. Wintjens R, Bozon D, Belabbas K, MBou F, Girardet JP, Tounian PA et al. Global molecular analysis and APOE mutations in a cohort of autosomal dominant hypercholesterolemia patients in France. Journal of Lipid Research. 2016; 57 (3): 482-91.

15. Lu K, Lee MH, Hazard S, Brooks-Wilson A, Hidaka H, Kojima H et al. Two genes that map to the STSL locus cause sitosterolemia: genomic structure and spectrum of mutations involving sterolin-1 and sterolin-2, encoded by ABCG5 and ABCG8, respectively. Am $J$ Hum Genet. 2001; 69 (2): 278-90.

16. De Backer G, Besseling J, Chapman J, Hovingh GK, Kastelein JJP, Kotseva $K$ et al. Prevalence and management of familial hypercholesterolaemia in coronary patients: An analysis of EUROASPIRE IV, a study of the European Society of Cardiology. Atherosclerosis. 2015; 241 (1): 169-75.

17. Nordestgaard BG, Chapman MJ, Humphries SE, Ginsberg HN, Masana L, Descamps OS et al. Familial hypercholesterolaemia is underdiagnosed and undertreated in the general population: guidance for clinicians to prevent coronary heart disease: consensus statement of the European Atherosclerosis Society. European Heart Journal. 2013; 34 (45): 3478-90a

18. Ежов М. В., Сергиенко И. В., Дупляков Д. В., Абашина О. Е., Качковский М. А., Шапошник И. И. и др. Результаты Российской научно-исследовательской программы по диагностике и лечению больных семейной гиперхолестеринемией. Высокая распространенность, низкая информированность, плохая приверженность. Атеросклероз и дислипидемии. 2017; (2): 5-15.

19. Захарова Ф. М., Татищева Ю. А., Голубков В. И., Липовецкий Б. М., Константинов В. О., Денисенко А. Д. и др. Семейная гиперхолестеринемия в Санкт-Петербурге: разнообразие мутаций свидетельствует об отсутствии выраженного 


\section{ORIGINAL RESEARCH I MEDICAL GENETICS}

эфффекта основателя. Генетика. 2007; 43 (9): 1255-62.

20. Корнева В. А., Богословская Т. Ю., Кузнецова Т. Ю., Мандельштам М. Ю., Васильев Б. В. Семейная гиперхолестеринемия, обсуловленная новой мутацией гена рецепторов липопротеинов низкой плотности. Клиническая медицина. 2014; (7): 49-53.

21. Шахтшнейдер Е. В., Макаренкова К. В., Астракова К. С., Иванощук Д. Е., Орлов П. С., Рагино Ю. И. и др. Таргетное секвенирование гена PCSK9 у пациентов семейной гиперхолестеринемией в России. Кардиология. 2017; (6) $46-51$.

22. Kosenko T, Golder M, Leblond G, Weng W, Lagace TA. Low density lipoprotein binds to proprotein convertase subtilisin/kexin type-9 (PCSK9) in human plasma and inhibits PCSK9-mediated low density lipoprotein receptor degradation. The Journal of biological chemistry. 2013; 288 (12): 8279-88.
23. Bennet AM, Di Angelantonio E, Ye Z, Wensley F, Dahlin A, Ahlbom A et al. Association of apolipoprotein $E$ genotypes with lipid levels and coronary risk. Jama. 2007; 298 (11): 1300-11.

24. Luo JQ, Ren H, Banh HL, Liu MZ, Xu P, Fang PF et al. The Associations between Apolipoprotein E Gene Epsilon2/Epsilon3/ Epsilon4 Polymorphisms and the Risk of Coronary Artery Disease in Patients with Type 2 Diabetes Mellitus. Frontiers in physiology. 2017; (8): 1031

25. Shakhtshneider EV, Ragino YI, Chernjavski AM, Kulikov IV, Ivanova MV, Voevoda MI. Apolipoprotein E gene polymorphism in men with coronary atherosclerosis in Siberia. Bulletin of experimental biology and medicine. 2011; 150 (3): 355-8.

26. Vandrovcova J, Thomas ER, Atanur SS, Norsworthy PJ, Neuwirth C Tan $Y$ et al. The use of next-generation sequencing in clinical diagnosis of familial hypercholesterolemia. Genet Med. 2013; 15 (12): 948-57. 